\title{
Identification and Characterization of Simple Sequence Repeats (SSR) Markers Associated with Downy Mildew Resistance Locus “RPV1" in Grapes
}

\author{
Neetu Goyal1', Akshay Nag1, Roshni R. Samarth ${ }^{2}$, Anuradha Upadhyay², Kashmir Singh1* \\ ${ }^{1}$ Department of Biotechnology, Panjab University, Chandigarh, India \\ ${ }^{2}$ National Research Centre for Grapes, Pune, India \\ Email: *kashmirbio@pu.ac.in
}

How to cite this paper: Goyal, N., Nag, A., Samarth, R.R., Upadhyay, A. and Singh, K. (2021) Identification and Characterization of Simple Sequence Repeats (SSR) Markers Associated with Downy Mildew Resistance Locus "RPVI" in Grapes. Advances in Bioscience and Biotechnology, 12, 371-387. https://doi.org/10.4236/abb.2021.1211024

Received: October 2, 2021

Accepted: November 26, 2021

Published: November 29, 2021

Copyright $\odot 2021$ by author(s) and Scientific Research Publishing Inc. This work is licensed under the Creative Commons Attribution International License (CC BY 4.0).

http://creativecommons.org/licenses/by/4.0/

\section{(c) (i) Open Access}

\begin{abstract}
The cultivation of grapes is severely impacted by the emergence of downy mildew (DM) disease which negatively affects quality and yield possibly resulting in heavy losses. Due to certain shortcomings in the usage of fungicides and the development of new cultivars by plant breeding, marker assisted selection (MAS) will be an efficient alternative method to introduce desired genes into the cultivated varieties in a short time period. The Simple sequence repeats (SSR) markers seem to be the most popular genetic marker of choice for MAS. In the present study, we identified 14 new SSR markers in RPVI locus that are associated with downy mildew resistance in grapes. The characterization of the identified markers was carried out on the basis of various parameters such as types of repeat motifs, number of repeats, different classes and structure of microsatellites. Additionally, SSR genotyping in 56 different grape accessions was done to determine the susceptibility or resistance of these accessions to DM.
\end{abstract}

\section{Keywords}

Downy Mildew, Resistance, Locus, Simple Sequence Repeats, Genotyping

\section{Introduction}

Grapes are one of the world's most widely cultivated horticultural crops, providing enormous nutritious products such as drinks, jellies and jams. Many fun- 
gal diseases severely impact their cultivation, and downy mildew (DM) is one of those destructive diseases that greatly affect the stem, leaf, shoot, and fruit. The causative agent of DM is the biotrophic obligate oomycete "Plasmopara viticola" that needs a living host to live [1] [2]. It is speculated that this fungus emerged in North America, and was inadvertently spread to other areas of the world [3]. The disease appears on young leaves as yellow circular oily spots surrounded by a brownish-yellow halo. Infection with downy mildew results in a significant drop in grape quality and productivity.

As a conventional preventive approach, diverse fungicides are used for both pre-infection and post-infection DM conditions. While the usage of fungicides may aid in managing DM, there are certain disadvantages to their application. The air quality decreases in grape growing areas, persistence of chemical residues may occur in grape products, and the development of fungicides resistant fungal strains can take place [4]. During the 19th century, the management of fungal diseases by genetic resistance was the paramount goal of the scientific community in grape breeding. Though the $V$. vinifera cultivars were found to be susceptible to $P$. viticola, many North American and Asian Vitis species such as Muscandinia rotundifolia, V. riparia, V. cinerea, V. labrusca, V. rupestris, V. berlandieri, $V$. lincecumii, show variable resistance levels to this pathogen [5]-[12]. The genetic basis of resistance to downy mildew was therefore examined and mapped in various genetic backgrounds.

In the grape genome, more than $13 P$. viticola major and minor Mendelian Resistance $(R)$ loci named " $R P V$ " have previously been found which provide DM resistance [13] [14] [15] [16] [17]. Several of these QTLs with significant effects on DM resistance were detected in LGs 4 and 18 in cultivar "Regent"; LGs 8, 12 and 17 in segregating populations of $V$. riparia and $V$. vinifera; LGs 9 and 12 in $V$. riparia; LG 14 in $V$. amurensis, LGs 1,6 and 7 in two interspecific hybrids cross inheriting $V$. rotundifolia and $V$. amurensis traits [13] [14] [16] [17] [18]. As documented in literature, the chromosomal locations of $R P V 1, R P V 2, R P V 3$, $R P V 8, R P V 10$ are $12,18,18,14,9$ respectively [13] [15]. Identification and localization of DM resistance loci from diverse backgrounds is valuable information that can be used by grape breeders to more efficiently utilize alternative DM resistance resources.

However, the breeding of new grape varieties is quite resource-intensive and time-consuming; therefore, an alternate method of Marker Assisted Selection (MAS) may also be used efficiently to integrate desirable genes into cultivated varieties. In grapes, considerable advances have been made in the production of MAS tools in recent times. A huge number of DNA sequence based markers such as amplified fragment length polymorphism (AFLP), diversity arrays technology markers (DArT), restriction fragment length polymorphism (RFLP), single nucleotide polymorphism (SNP), and simple sequence repeats (SSRs) associated with the gene of interest were created previously. Such markers can be used to generate genetic linkage maps to identify genomic regions that are linked 
to specific trait of interest [19] [20].

Amongst several, the most widely used marker type is simple sequence repeats (SSR) markers, also called microsatellites, short tandem repeats (STR), and simple sequence length polymorphisms (SSLP) [21] [22]. These are the short, repetitive nucleotide motifs of 1 to 6 base pairs dispersed across most eukaryotic species' genomes [23]. Litt and Luty first provided the term "microsatellite" in 1989 to describe the simple sequence stretches amplified by PCR [24]. They can be used for multiple purposes, such as genetic map construction, genetic variation study, phylogenetic studies to create evolutionary trees, and MAS [25].

The publishing of the whole $V$. vinifera genome speeds up the development of new SSR markers which can be used to pyramidize resistance from various grape varieties utilizing MAS technique [26]. In the present study, we identified various SSR markers in RPV1 locus of grape genome that are known for providing resistance to downy mildew. The markers identified were subsequently used for analyzing 56 different $V$. vinifera accessions for susceptibility or resistance to DM.

\section{Material and Methods}

\subsection{Identification of SSR Markers Linked to DM Resistance in RPV1 Locus in Grapevine}

\subsubsection{Sequence Data}

The genomic sequence of $R P V 1$ locus was retrieved from NCBI

(https://www.ncbi.nlm.nih.gov/). The locus I.D for the extracted sequence was JQ904634.1 [27].

\subsubsection{Marker Identification and Primer Designing}

To identify SSR markers linked to RPV1 locus, the "FASTA" file of the above sequence was submitted to "WebSat" online program (https://bioinfo.inf.ufg.br/websat/) [28]. For analysis, the criteria for marker motif length was di to hexa nucleotide repeat motif; minimum number of 4 motif repetitions was chosen for di-, tri-, and tetra-nucleotide repeats; minimum of 2 motif repetitions was chosen for penta- and hexa-nucleotide repeats; mononucleotides were excluded from the analysis. Its means that for di-nucleotide repeat motifs, the minimum repeat number was kept as 4 and maximum was 12 . Likewise, the same criteria was followed for other types of repeats. Next, the SSR finder program processed the sequence and highlighted several regions which contained SSR markers in an output. Next, the BLASTX of the regions having SSR markers as obtained from "Websat" was performed to find blast homology with TIR-NB-LRR type resistant proteins so as to make it easier for further screening on the basis of $\mathrm{R}$ proteins. Consequently, such sequences were identified that showed the highest identity with TIR-NB-LRR type resistant proteins. Next, the BLASTX of the regions with SSR markers as obtained from "Websat" was performed to find blast homology with TIR-NB-LRR type resistant proteins. 
As a result, such sequences which showed the highest identity with TIR-NB-LRR type resistant proteins were identified. Thereafter, the primers were designed using the same tool. The primer designing software on which Websat works is Primer 3. The parameters used for primer designing were: the primer size range is 18 - 25; Primer $\mathrm{T}_{\mathrm{m}}: 57^{\circ} \mathrm{C}-68^{\circ} \mathrm{C}$; GC content: $40 \%$ - 60\%; Product size: 150 $550 \mathrm{bp}$; and rest of the parameters were set at default values.

\subsection{SSR Analysis}

The characterization of SSRs was done to test the specificity of SSRs in grapes. Various SSR characteristics analyzed were types of SSR motifs, number of repeats, different classes and structure of microsatellites.

\subsection{SSR Genotyping}

\subsubsection{Plant Material and DNA Extraction}

The leaf tissues of different grape accessions were collected from National Research Centre for Grapes (NRCG), Pune (Table S1). Total genomic DNA was isolated from the leaf samples obtained and the protocol given by Dellaporta et al., 1983 was followed [29]. The quality and integrity of the extracted DNA was checked on $0.8 \%$ agarose gel. The quantification and purity of DNA were assessed on a nano-spectrophotometer (Eppendorf, USA). The purity of DNA sample was determined by measuring the absorbance at 260 $\mathrm{nm}$ and $280 \mathrm{~nm}$.

\subsubsection{Primer Validation}

For the validation of effective SSR primers associated with downy mildew resistance, the PCR amplifications were done using a single $V$. vinifera accession "Perlette". The following components were added in PCR tube to make a final mixture of $25 \mu \mathrm{l}$ : $10 \times$ PCR buffer (Supplied by the manufacturer) $-2.5 \mathrm{ml}$; dNTPs $(10 \mathrm{mM})-0.5 \mu \mathrm{l}$; Forward primer $(10 \mu \mathrm{M})-0.5 \mu \mathrm{l}$; Reverse primer $(10$ $\mu \mathrm{M})-0.5 \mu \mathrm{l}$; DNA (50 - $100 \mathrm{ng})-0.5 \mu \mathrm{l} ; \mathrm{MgCl}_{2}(25 \mathrm{mM})-2.5 \mu \mathrm{L}$; Taq polymerase ( 5 units $/ \mu \mathrm{l})-0.25 \mu \mathrm{l}$. The volume make-up was done with nuclease free water. The forward and reverse primers that were added to master-mix are given in Table S2. All components were mixed well and PCR was performed (Bio-Rad $\mathrm{T}_{100}{ }^{\mathrm{TM}}$ Thermal Cycler) with PCR conditions mentioned in Table S2 for RPV1 associated markers. PCR products were analysed on $2.5 \%$ agarose gel.

\subsubsection{Genotyping in Different Grape Accessions and Data Analysis}

After validation of the amplification of SSR markers at the appropriate annealing temperature, amplifications were done in extracted DNA of various grape accessions. The amplification of polymorphic markers at a specific band size indicates whether that variety is downy mildew susceptible or resistant as compared to positive control i.e. Muscandinia rotundifolia. The genotyping results were processed manually to check for the presence or absence of SSR markers amplification bands in different accessions. 


\section{Results and Discussion}

\subsection{Identification of SSR Markers Associated with Downy Mildew Resistance}

Simple sequence repeats (SSRs) are $1-6$ bp long, tandem-repeated genomic segments that prevail in both coding and non-coding regions [30]. They are extensively used in molecular genetics and plant breeding areas due to their abundance, multi-allelism, co-dominance, ubiquity and variation etc. [31]. As SSR markers and QTLs are known to be associated with each other, the RPVI locus of grape genome was examined to identify highly polymorphic SSR markers.

\subsubsection{Sequence Retrieval}

The RPVI locus resides on chromosome 12 of grape genome. As identified in literature, the total region of $R P V 1$ locus detected is upto $7 \mathrm{Mb}$ from $13.10-20.37$ $\mathrm{Mb}$ between the markers VMC4f3-1 and VMC8g9 in Muscandinia rotundifolia [27]. The region between 16.752623 and $16.755849 \mathrm{Mb}$ on chromosome 12 is found to be coding for RGA8; a full length TIR-NBS-LRR gene (also called RPVI gene) [27]. We have analyzed the genomic sequence of this region for the identification of SSR markers. The locus ID for this sequence is JQ904634 and the total length of sequence analyzed is up to $14,677 \mathrm{bp}$.

\subsubsection{Marker Identification and Primer Designing}

For analysis, the genomic sequence was retrieved from NCBI and analyzed at "Websat" to identify various SSR markers. Initially, a large number of sequences with a repeat number of 2 to 6 for penta- and hexa-nucleotide motifs; repeat number of 4 to 6 for di-, tri- and tetra-nucleotide motifs were generated. Then, after screening for the presence of TIR, NBS and LRR domains in SSR marker containing sequences, a total of 14 such sequences were identified that shared blast homology with TIR-NBS-LRR domains and consisted of SSR markers. Thus, in total, 14 SSR markers associated with DM resistance were identified. Also, as the SSRs were identified in gene coding region, they are fewer in number. The primers were designed by using the same software. The primer name, marker category and repeat sequence are given in Table 1. Because of their wide use in multiple applications such as genotyping, mapping and breeding, the development of SSR markers in grapes was also done previously [32] [33] [34]. In the present study, we have focused on the identification of SSR markers associated with downy mildew resistant locus " $R P V I$ " in grapes.

\subsection{Characterization of SSRs}

The region of $R P V 1$ locus analyzed was genomic sequence consisting of both introns and exons. However, the SSR markers were developed after confirming through BLASTX for the presence of TIR-NBS-LRR domains, therefore we can say that the markers are developed from the exonic regions, thus the markers are EST-SSRs (Expressed sequenced tagged microsatellites) or Genic. Such types of markers (EST-SSRs) have also been detected previously in several plants, such as 
Table 1. The list of primer name, marker category and repeat sequence for $R P V 1$ locus associated SSR markers.

\begin{tabular}{ccc}
\hline Primer Name & Marker category & Repeat Sequence \\
\hline ATAAA & penta-nucleotide repeat & ATAAA \\
TCT & tri-nucleotide repeat & TCT \\
AAT & tri-nucleotide repeat & AAT \\
TAAAAA & hexa-nucleotide repeat & TAAAAA \\
ATTT & tetra-nucleotide repeat & ATTT \\
TATCTC & hexa-nucleotide repeat & TATCTC \\
AGGAG & penta-nucleotide repeat & AGGAG \\
TC & di-nucleotide repeat & TC \\
AGAGGG & hexa-nucleotide repeat & AGAGGG \\
TTCTTT & hexa-nucleotide repeat & TTCTTT \\
TATCTC & hexa-nucleotide repeat & TATCTC \\
GTAAT & penta-nucleotide repeat & GTAAT \\
TGAAT & penta-nucleotide repeat & TGAAT \\
GAAGT & penta-nucleotide repeat & GAAGT \\
\hline
\end{tabular}

alfalfa, barley, rice and maize [35] [36] [37] [38]. The primers were also designed from the coding regions, hence the primers designed were exonic and were designed to amplify the coding region of the locus.

The motif characterization was done on the basis of repeat motif type and number of repeats. The repeat motif for microsatellites can be mononucleotide, dinucleotide, trinucleotide, tetranucleotide, pentanucleotide and hexanucleotide repeats [39]. Through analysis, a total of 1 di-; 2 tri-; 1 tetra-; 5 penta- and 5 hexa-nucleotide repeat motifs were identified in 14 SSR markers. In plants, the most commonly found microsatellites are di-nucleotide motifs consisting of $(\mathrm{GT})_{\mathrm{n}}$ and $(\mathrm{AT})_{\mathrm{n}}$ repeats [40] [41]. However, the di-nucleotide repeat motif obtained in our study is (TC) $)_{n}$ repeats. The occurrence of tri-nucleotides and tetra-nucleotides in plant genomes is also reported, the commonly observed are $(\mathrm{AAG})_{\mathrm{n}}$ and $(\mathrm{AAT})_{\mathrm{n}}$ [30]. We also got one $(\mathrm{AAT})_{\mathrm{n}}$ tri-nucleotide motif in our analysis. The frequency of occurrence of different types of repeat motifs is penta-/hexa- > tri- > di-/tetra-nucleotide repeat motifs (Figure 1). Penta- and hexa-nucleotide repeat motifs were present in maximum number, whereas di- and tetra-nucleotide repeat motifs were found in minimum number (Figure 1). The advantage of getting higher number of penta-/hexa nucleotide repeat motifs is that there are lesser chances of getting mutations due to longer repeat length, thus the gene expression will not be compromised. As the resistant locus analyzed in this study is known for having resistance (R) genes that provide resistance, therefore it is necessary that the gene frame should not be altered because 
Frequencies of different nucleotide repeat motifs inthe SSRs

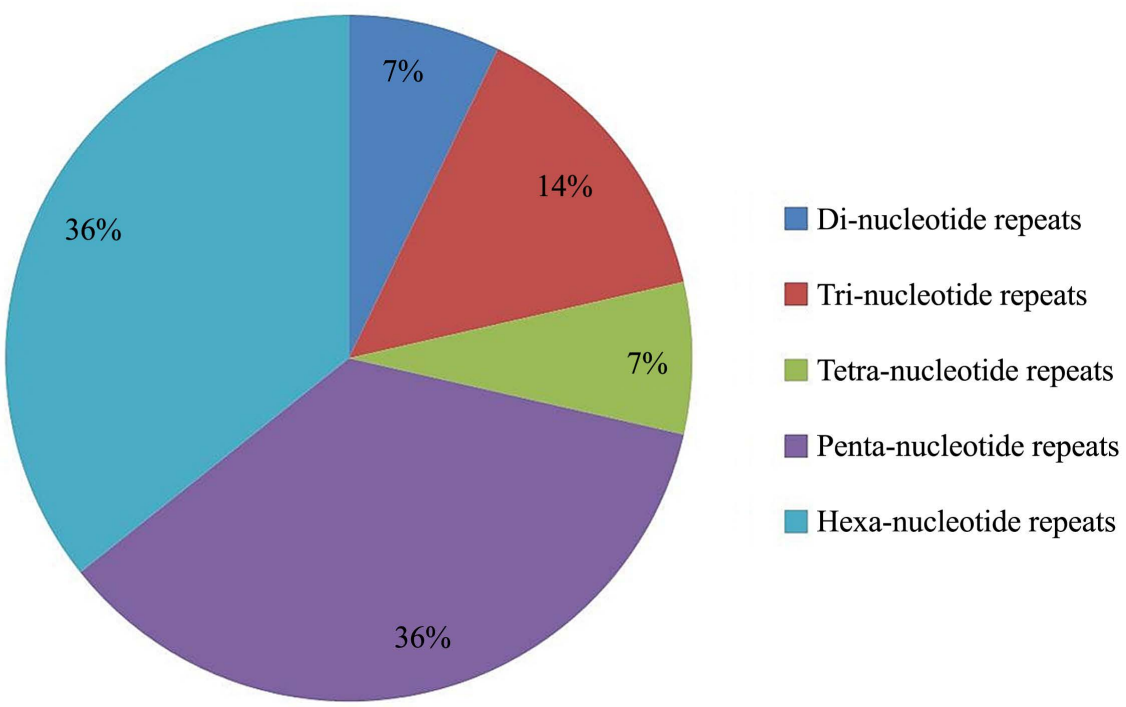

Figure 1. Pie chart representing the distribution of different nucleotide repeat motifs in $R P V 1$ locus associated SSRs.

that might disrupt the gene function. Therefore, it is advantageous that we got higher number of penta-/hexa nucleotide repeat motifs as compared to di-, triand tetra-nucleotide repeat motifs. There are lesser chances of getting mutations due to longer repeat length, thus the gene expression would not be compromised.

Next, the repeat number for SSR markers was analyzed and it was observed that the repeat number varied from 2 to 6 (Figure 2). The maximum repeat number of 6 was found in one SSR marker consisting of di-nucleotide repeat motif; the repeat number of 5 was also found in one SSR marker consisting of tri-nucleotide repeat motif; the repeat number of 4 was found in two SSR markers consisting of tri- and tetra-nucleotide repeat motifs and the repeat number of 2 was found in ten SSR markers consisting of penta- and hexa-nucleotide repeat motifs (Figure 2). The reason for the differences in number of repeats of a particular motif at a locus in different individuals is recombination errors, DNA strand slippage during replication, mismatches, and retro-transposition [42]. Next, the SSR markers were grouped into different classes depending upon the length of repeat motifs. Generally, if the length of SSR repeat is $20 \mathrm{bp}$ or more, they are considered Class 1 repeats; between 12 - 20 bps-Class 2 repeats; and if the length is less than 12 -Class 3 repeats. In our analysis, we found 7 SSR markers to be between 12 - 20 bps; hence they are considered as Class 2 repeats. Likewise, in class 3 repeats category also, we got 7 SSR markers. In class 1 category, no SSR marker was detected.

The different types of arrangement for microsatellites can categorize the repeats into simple and compound repeats. Simple repeats are composed of multiple repeats of two or more nucleotides like $\left(\mathrm{N}_{1} \mathrm{~N}_{2} \ldots \mathrm{N}_{\mathrm{x}}\right)_{\mathrm{n}}$ whereas compound repeats can have two or more adjoining repeats of motifs such as $(C A)_{n}(G T)_{n}$, or 


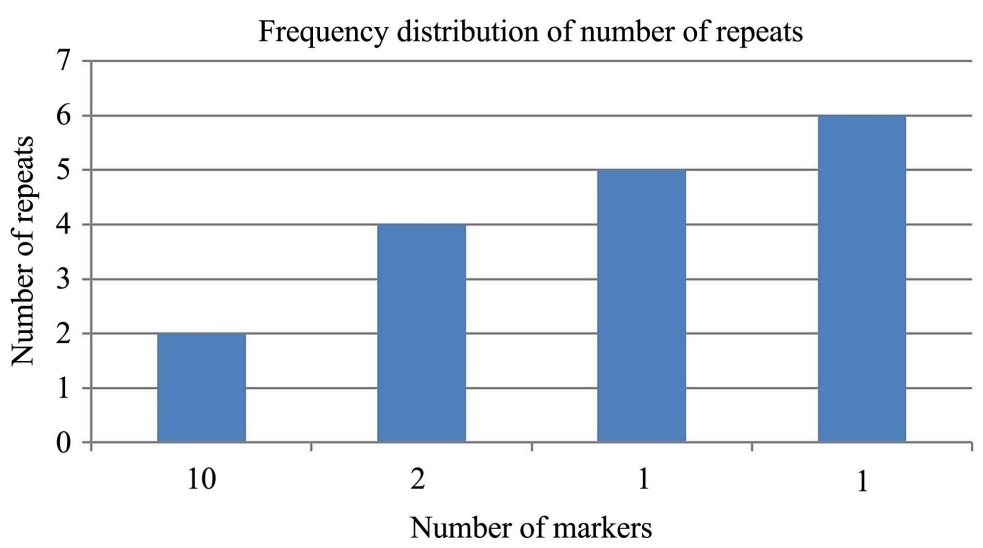

Figure 2. Bar graph representing the frequency distribution of number of repeats in different SSR markers.

$(d C-d A)_{n}(d G-d T)_{n}[19]$. The structure of all the SSR markers designed in our study consisted of only 1 type of repetitive unit, hence they are called simple repeats.

\subsection{SSR Genotyping}

Microsatellites are the widely used genetic markers in plant breeding programs due to their properties such as co-dominant markers, wide distribution, high polymorphism levels, and high abundance in genome [21] [43]. Polymorphism detection is done after the amplification of SSR markers through PCR accompanied by interpretation and evaluation of band patterns observed after agarose gel electrophoresis [21] [44].

\subsubsection{DNA Isolation}

Total genomic DNA was isolated from leaf tissues of 56 different $V$. vinifera accessions collected from NRCG, Pune by using the method described by Dellaporta et al., 1983 [29]. The absorbance ratio of 260/280 indicated that the DNA was relatively free of proteins and contaminants. The reason for choosing these varieties is that the identification of $R P V$ loci has previously been done in American and Central Asian varieties only, we checked their presence in Indian cultivars [5]-[12]. Presently, there is no commercial table grape variety in India that is resistant to downy mildew, therefore, it is necessary to screen as much grape germplasm as possible to identify the resistant traits in different grape varieties.

\subsubsection{Screening of SSR Primers for Downy Mildew Resistance}

For the screening of SSR primers associated with downy mildew resistance, the PCR amplification of SSR markers was performed in "Perlette" variety of $V$. vinifera and analysed on $2.5 \%$ agarose gel. This variety was chosen because of its easy availability in our region. "Perlette" was primarily obtained in California in 1936 by Harold P. Olmo through crossbreeding between Sultanine and Reine des Vignes varieties of Vitis vinifera. The PCR conditions used were: $3 \mathrm{~min}$ at $94^{\circ} \mathrm{C}$, 
35 cycles $\left(94^{\circ} \mathrm{C}\right.$ for $30 \mathrm{~s}$, Tm for $30 \mathrm{sec}, 72^{\circ} \mathrm{C}$ for $\left.1 \mathrm{~min}\right), 7 \mathrm{~min}$ at $72^{\circ} \mathrm{C}$. As a result of analysis, 12 out of 14 primer pairs were successfully screened for performing amplification. The $R P V 1$ locus associated with SSR-PCR products were amplified between $48^{\circ} \mathrm{C}-53^{\circ} \mathrm{C}$ (Table 2 ). The maximum band size obtained was $390 \mathrm{bp}$ for 3 markers, and minimum band size was $200 \mathrm{bp}$ for 1 marker (Table 2).

\subsubsection{Amplification of SSR Markers Associated with RPV1 Locus in Different Genotypes}

After validation of SSR markers amplification at the specific annealing temperature, amplifications were done in DNA isolated from 56 different $V$. vinifera accessions. The amplification of these polymorphic markers at a particular band size indicates whether that variety is susceptible or resistant to downy mildew. Out of 12, 6 SSR markers namely ATT, TCT, GTAAT, AGGAG, TTCTTT, AGAGGG showed amplifications. The genomic DNA of Muscandinia rotundifolia was also used in the PCRs as a positive control depicting the standard marker allele size associated with resistance. This species of "Vitis" has co-evolved with "Plasmopara viticola" in North America; therefore, it tolerates/resists the infection caused by DM [45].

\subsubsection{Data Analysis}

All SSR fragments were screened manually and converted to " 1 " and " 0 " binary digits for the presence of band and absence of band (Table 3). The comparative analysis of grapevine accessions with $M$. rotundifolia showed that there were certain varieties showing the presence or absence of respective allelic bands in

Table 2. The list of SSR markers of RPVI locus with the attained Tm (annealing temperature) and band size.

\begin{tabular}{ccc}
\hline Marker & $\mathrm{Tm}$ & Band Size attained (bp) \\
\hline TCT & $52^{\circ} \mathrm{C}$ & $\sim 290$ \\
TAAAAA & $52^{\circ} \mathrm{C}$ & $\sim 350$ \\
ATT & $52^{\circ} \mathrm{C}$ & $\sim 210$ \\
AGGAG & $52^{\circ} \mathrm{C}$ & $\sim 330$ \\
AGAGGG & $52^{\circ} \mathrm{C}$ & $\sim 520$ \\
GTAAT & $52^{\circ} \mathrm{C}$ & $\sim 300$ \\
GAAGT & $52^{\circ} \mathrm{C}$ & $\sim 390$ \\
TGAAT & $52^{\circ} \mathrm{C}$ & $\sim 200$ \\
TATCTC & $53^{\circ} \mathrm{C}$ & $\sim 350$ \\
TTCTTT & $51^{\circ} \mathrm{C}$ & $\sim 300$ \\
AAT & $48^{\circ} \mathrm{C}$ & $\sim 390$ \\
ATAAA & $48^{\circ} \mathrm{C}$ & $\sim 390$ \\
\hline
\end{tabular}


Table 3. Chart showing the scoring of RPV1 locus associated SSR markers in binary digit format (" 1 " for presence of band and " 0 " for absence of band). " 0 " indicated the opposite trend of presence/absence of SSR markers with respect to positive control having value " 1 ".

\begin{tabular}{|c|c|c|c|c|c|c|}
\hline Variety & GTAAT & TTCTTT & ATT & AGGAG & AGAGGG & TCT \\
\hline Muscandinia Rotundifolia & 1 & 1 & 1 & 1 & 1 & 1 \\
\hline Kattakurghan & 0 & 0 & 0 & 1 & 0 & 0 \\
\hline Black Monukka & 1 & 1 & 1 & 1 & 1 & 1 \\
\hline Palomino & 1 & 1 & 1 & 1 & 1 & 1 \\
\hline Italian Eliquena & 0 & 0 & 1 & 1 & 0 & 1 \\
\hline Red Globe & 0 & 0 & 1 & 1 & 0 & 1 \\
\hline Chardony & 0 & 0 & 1 & 1 & 1 & 1 \\
\hline Red Muscat & 1 & 0 & 0 & 1 & 0 & 1 \\
\hline Madhu Angoor & 0 & 0 & 0 & 0 & 0 & 1 \\
\hline Viognier & 0 & 0 & 1 & 0 & 0 & 1 \\
\hline Vitis Labrusca & 0 & 0 & 0 & 1 & 0 & 0 \\
\hline Kishmish Belyi & 0 & 1 & 1 & 0 & 1 & 1 \\
\hline Pandhari Sahebi & 1 & 0 & 0 & 0 & 0 & 0 \\
\hline Anab-e-Shahi & 0 & 0 & 1 & 0 & 0 & 1 \\
\hline Country Banglore & 0 & 0 & 1 & 0 & 0 & 1 \\
\hline Black Damas Rose & 0 & 0 & 0 & 0 & 0 & 0 \\
\hline Hussain Kadu & 0 & 0 & 0 & 1 & 0 & 0 \\
\hline Golden Queen & 0 & 0 & 1 & 1 & 0 & 1 \\
\hline Black Champa & 0 & 0 & 0 & 1 & 0 & 0 \\
\hline Doradillo & 0 & 1 & 1 & 1 & 1 & 1 \\
\hline Alden & 1 & 1 & 1 & 1 & 1 & 1 \\
\hline Bianca & 1 & 1 & 1 & 1 & 1 & 1 \\
\hline Castiza & 1 & 1 & 1 & 1 & 1 & 1 \\
\hline Black Hamburg & 1 & 0 & 0 & 0 & 1 & 0 \\
\hline Charas & 1 & 1 & 0 & 0 & 0 & 0 \\
\hline Champion & 0 & 0 & 1 & 1 & 0 & 0 \\
\hline Convent large Black & 0 & 1 & 1 & 1 & 1 & 1 \\
\hline Barbarossa & 1 & 1 & 1 & 1 & 1 & 1 \\
\hline Black Round & 1 & 1 & 1 & 1 & 1 & 1 \\
\hline Concord & 1 & 1 & 1 & 1 & 1 & 1 \\
\hline Kishmish Rozavis & 1 & 1 & 0 & 1 & 1 & 1 \\
\hline
\end{tabular}




\section{Continued}

\begin{tabular}{|c|c|c|c|c|c|c|}
\hline Diamond Jubilee & 1 & 1 & 1 & 1 & 1 & 0 \\
\hline Chasselas Blanc & 1 & 1 & 1 & 1 & 1 & 1 \\
\hline Fantasy Seedless & 1 & 0 & 0 & 1 & 1 & 1 \\
\hline Cheema Sahebi & 1 & 1 & 0 & 1 & 1 & 0 \\
\hline Crimson seedless & 1 & 1 & 0 & 1 & 1 & 0 \\
\hline Sirius & 1 & 1 & 0 & 0 & 1 & 0 \\
\hline Trebbiano & 1 & 0 & 0 & 0 & 0 & 0 \\
\hline Garganega & 0 & 0 & 0 & 1 & 0 & 0 \\
\hline Tsimlyanski Chernyi & 0 & 0 & 0 & 0 & 0 & 0 \\
\hline Athens & 0 & 0 & 0 & 1 & 0 & 0 \\
\hline Sahebi Ali & 0 & 0 & 0 & 1 & 1 & 0 \\
\hline Peru white & 0 & 0 & 0 & 1 & 1 & 0 \\
\hline Champanel & 1 & 0 & 0 & 0 & 0 & 0 \\
\hline Grenache & 1 & 0 & 0 & 0 & 0 & 0 \\
\hline Red Prince & 0 & 1 & 0 & 1 & 1 & 0 \\
\hline Banglore Blue & 0 & 0 & 0 & 1 & 0 & 0 \\
\hline Pearl of casaba & 1 & 1 & 0 & 1 & 1 & 0 \\
\hline Tempranillo & 0 & 0 & 0 & 1 & 1 & 0 \\
\hline Cinsault & 1 & 1 & 0 & 1 & 1 & 0 \\
\hline Maroo Seedless & 1 & 1 & 0 & 1 & 1 & 0 \\
\hline Reisling & 1 & 1 & 1 & 1 & 1 & 1 \\
\hline Cabernet Sauvignan & 1 & 1 & 1 & 1 & 1 & 1 \\
\hline CBR & 1 & 1 & 1 & 1 & 1 & 1 \\
\hline SV 12309 & 1 & 1 & 1 & 1 & 0 & 1 \\
\hline SV 123640 & 1 & 1 & 0 & 0 & 0 & 1 \\
\hline
\end{tabular}

comparison to $M$. rotundifolia. As analyzed from results, in M. rotundifolia, the amplification bands were observed for all the finally screened six markers. As $M$. rotundifolia is used as positive control, the grapevine varieties showing an opposite trend of presence/absence of SSR markers could be putatively associated with susceptibility to DM. As analyzed from results, for GTAAT marker, out of $56,24 \mathrm{~V}$. vinifera accessions could be putatively associated with susceptibility to DM. Likewise, for TTCTTT, ATT, AGGAG, AGAGGG and TCT markers; 26, $29,15,25$ and $27 V$. vinifera accessions could be putatively associated with susceptibility to DM.

\section{Conclusion}

In the present study, we identified and characterized various SSR markers in 
$R P V 1$ locus that are known to be associated with downy mildew resistance in grapes. Their genotyping was done to detect polymorphisms in grape germplasm using Muscandinia rotundifolia (wild North American Vitis species resistant to downy mildew) as a positive control. Altogether, the development and genotyping of SSR markers would further assist in illustrating the complex genetic traits and advancement of molecular breeding in grapes.

\section{Acknowledgements}

The authors express their sincere gratitude to Department of Biotechnology (DBT), India for providing financial assistance. NG is thankful to Department of Biotechnology (DBT), India for providing junior and senior research fellowship.

\section{Funding}

The study was funded by Department of Biotechnology (DBT), India under the project entitled "An integrated approach of molecular breeding for downy and powdery mildew resistance in grape".

\section{Availability of Data and Material}

The plant materials used during the current study are available from the authors upon request.

\section{Authors' Contributions}

NG-perform wetlab experiment, analysis of Grape sequences, primers designing and manuscript writing; $\mathrm{AN}$-helps in bioinformatics analysis of RPV locus and identification of SSR markers, helped in finalizing the manuscript; RRS, AU-provided plant material, helped in isolation of DNA and primer designing; $\mathrm{KS}$ - conceived the idea, designed the experiments, overall supervision and finalize the manuscript.

\section{Conflicts of Interest}

All the authors declare that there is no conflict of interest.

\section{References}

[1] Gessler, C., Pertot, I. and Perazzolli, M. (2011) Plasmopara viticola: A Review of Knowledge on Downy Mildew of Grapevine and Effective Disease Management. Phytopathologia Mediterranea, 50, 3-44.

[2] Berlese, A.N. and de Toni, J.B. (1888) In Saccardo, Sylloge Fungorum Omnium Hucusque Cognitorum, VII. (Pars. I) Phycomyceteae Auctoribus, Peronosporaceae, 233-264.

[3] Müller, K. and Sleumer, H. (1934) Biologische Untersuchungen über die Peronosporakrankheit des Weinstocks. Landwirtsch Jahrbücher, 4, 76-509.

[4] Pimentel, D. (2005) Environmental and Economic Costs of the Application of Pesticides Primarily in the United States. Environment, Development and Sustainability, 7, 52-229. https://doi.org/10.1007/s10668-005-7314-2 
[5] Diez-Navajas, A.M., Wiedemann-Merdinoglu, S., Greif, C. and Merdinoglu, D. (2008) Nonhost versus Host Resistance to the Grapevine Downy Mildew, Plasmopara viticola, Studied at the Tissue Level. Phytopathology, 98, 776-780. https://doi.org/10.1094/PHYTO-98-7-0776

[6] Dai, G.H., Andary, C., Mondolot-Cosson, L. and Boubals, D. (1995) Histochemical Studies on the Interaction between Three Species of Grapevine, Vitis vinifera, $V$. rupestris and $V$. rotundifolia and the Downy Mildew Fungus, Plasmopara viticola. Physiological and Molecular Plant Pathology, 46, 177-188. https://doi.org/10.1006/pmpp.1995.1014

[7] Denzer, H., Staudt, G. and Schlösser, E. (1995) Das Verhalten von Plasmopara viticola auf resistenten und anfälligen Rebsorten. Vitis, 34, 113-117.

[8] Staudt, G. and Kassemeyer, H.H. (1995) Evaluation of Downy Mildew Resistance in Various Accessions of Wild Vitis Species. Vitis, 34, 225-228.

[9] Brown, M.V., Moore, J.N., Fenn, P. and McNew, R.W. (1999) Evaluation of Grape Germplasm for Downy Mildew Resistance. Fruit Varieties Journal, 53, 22-29.

[10] Kortekamp, A. and Zyprian, E. (2003) Characterization of Plasmopara-Resistance in Grapevine Using in Vitro Plants. Journal of Plant Physiology, 160, 1393-1400. https://doi.org/10.1078/0176-1617-01021

[11] Unger, S., Büche, C., Boso, S. and Kassemeyer, H.H. (2007) The Course of Colonization of Two Different Vitis Genotypes by Plasmopara viticola Indicates Compatible and Incompatible Host-Pathogen Interactions. Phytopathology, 97, 780-786. https://doi.org/10.1094/PHYTO-97-7-0780

[12] Cadle-Davidson, L. (2008) Variation within and between Vitis spp. for Foliar Resistance to the Downy Mildew Pathogen Plasmopara viticola. Plant Disease, 92, 1577-1584. https://doi.org/10.1094/PDIS-92-11-1577

[13] Marguerit, E., Boury, C., Manicki, A., Donnart, M., Butterlin, G., Némorin, A., Wiedemann-Merdinoglu, S., Merdinoglu, D., Ollat, N. and Decroocq, S. (2009) Genetic Dissection of Sex Determinism, Inflorescence Morphology and Downy Mildew Resistance in Grapevine. Theoretical and Applied Genetics, 118, 1261-1278. https://doi.org/10.1007/s00122-009-0979-4

[14] Fischer, B.M., Salakhutdinov, I., Akkurt, M., Eibach, R., Edwards, K.J., Toepfer, R. and Zyprian, E.M. (2004) Quantitative Trait Locus Analysis of Fungal Disease Resistance Factors on a Molecular Map of Grapevine. Theoretical and Applied Genetics, 108, 501-515. https://doi.org/10.1007/s00122-003-1445-3

[15] Bellin, D., Peressotti, E., Merdinoglu, D., Wiedemann-Merdinoglu, S., Adam-Blondon, A.F., Cipriani, G., Morgante, M., Testolin, R. and Di Gaspero, G. (2009) Resistance to Plasmopara viticola in Grapevine "Bianca" Is Controlled by a Major Dominant Gene Causing Localised Necrosis at the Infection Site. Theoretical and Applied Genetics, 120, 163-176. https://doi.org/10.1007/s00122-009-1167-2

[16] Welter, L.J., Göktürk-Baydar, N., Akkurt, M., Maul, E., Eibach, R., Töpfer, R. and Zyprian, E.M. (2007) Genetic Mapping and Localization of Quantitative Trait Loci Affecting Fungal Disease Resistance and Leaf Morphology in Grapevine (Vitis vinifera L). Molecular Breeding, 20, 359-374.

https://doi.org/10.1007/s11032-007-9097-7

[17] Moreira, F.M., Madini, A., Marino, R., Zulini, L., Stefanini, M., Velasco, R., Kozma, P. and Grando, M.S. (2011) Genetic Linkage Maps of Two Interspecific Grape Crosses (Vitis spp.) Used to Localize Quantitative Trait Loci for Downy Mildew Resistance. Tree Genetics \& Genomes, 7, 153-167. https://doi.org/10.1007/s11295-010-0322-x 
[18] Blasi, P., Blanc, S., Wiedemann-Merdinoglu, S., Prado, E., Rühl, E.H., Mestre, P. and Merdinoglu, D. (2011) Construction of a Reference Linkage Map of Vitis amurensis and Genetic Mapping of Rpv8, a Locus Conferring Resistance to Grapevine Downy Mildew. Theoretical and Applied Genetics, 123, 43-53. https://doi.org/10.1007/s00122-011-1565-0

[19] Rakoczy-Trojanowska, M. and Bolibok, H. (2004) Characteristics and a Comparison of Three Classes of Microsatellite-Based Markers and Their Application in Plants. Cellular and Molecular Biology Letters, 9, 221-238.

[20] Di Gaspero, G., Cipriani, G., Adam-Blondon, A.F. and Testolin, R. (2007) Linkage Maps of Grapevine Displaying the Chromosomal Locations of 420 Microsatellite Markers and 82 Markers for R-Gene Candidates. Theoretical and Applied Genetics, 114, 1249-1263. https://doi.org/10.1007/s00122-007-0516-2

[21] Tautz, D. (1989) Hypervariability of Simple Sequences as a General Source for Polymorphic DNA Markers. Nucleic Acids Research, 17, 6463-6471. https://doi.org/10.1093/nar/17.16.6463

[22] Schlotteröer, C., Amos, B. and Tautz, D. (1991) Conservation of Polymorphic Simple Sequence Loci in Cetacean Species. Nature, 354, 63-65. https://doi.org/10.1038/354063a0

[23] Miah, G., Rafii, M.Y., Ismail, M.R., Puteh, A.B., Rahim, H.A., Islam, K. and Latif, M.A. (2013) A Review of Microsatellite Markers and Their Applications in Rice Breeding Programs to Improve Blast Disease Resistance. International Journal of Molecular Sciences, 14, 22499-22528. https://doi.org/10.3390/ijms141122499

[24] Litt, M. and Luty, J.A. (1989) A Hypervariable Microsatellite Revealed by in Vitro Amplification of a Dinucleotide Repeat within the Cardiac Muscle Actin Gene. American Journal of Human Genetics, 44, 397-401.

[25] Parida, S.K., Kalia, S.K., Kaul, S., Dalal, V., Hemaprabha, G., Selvi, A., Pandit, A., Singh, A., Gaikwad, K., Sharma, T.R., Srivastava, P.S., et al. (2009) Informative Genomic Microsatellite Markers for Efficient Genotyping Applications in Sugarcane. Theoretical and Applied Genetics, 118, 327-338. https://doi.org/10.1007/s00122-008-0902-4

[26] Jaillon, O., Aury, J.M., Noel, B., Policriti, A., Clepet, C., Cassagrande, A., Choisne, N., Aubourg, S., Vitulo, N., Jubin, C. and Vezzi, A. (2007) The Grapevine Genome Sequence Suggests Ancestral Hexaploidization in Major Angiosperm Phyla. Nature, 449, 463-467. https://doi.org/10.1038/nature06148

[27] Feechan, A., Anderson, C., Torregrosa, L., Jermakow, A., Mestre, P., Wiedemann-Merdinoglu, S., Merdinoglu, D., Walker, A.R., Cadle-Davidson, L., Reisch, B. and Aubourg, S. (2013) Genetic Dissection of a TIR-NB-LRR Locus from the Wild North American Grapevine Species Muscadinia rotundifolia Identifies Paralogous Genes Conferring Resistance to Major Fungal and Oomycete Pathogens in Cultivated Grapevine. The Plant Journal, 76, 661-674. https://doi.org/10.1111/tpj.12327

[28] Martins, W.S., Lucas, D.C.S., de Souza Neves, K.F. and Bertioli, D.J. (2009) WebSat-A Web Software for Microsatellite Marker Development. Bioinformation, 3, 282-283. https://doi.org/10.6026/97320630003282

[29] Dellaporta, S.L., Wood, J. and Hicks, J.B. (1983) A Plant DNA Minipreparation: Version II. Plant Molecular Biology Reporter, 1, 19-21.

https://doi.org/10.1007/BF02712670

[30] Gupta, P.K., Balyan, H.S., Sharma, P.C. and Ramesh, B. (1996) Microsatellites in Plants: A New Class of Molecular Markers. Current Science, 70, 45-54.

[31] Powell, W., Machray, G.C. and Provan, J. (1996) Polymorphism Revealed by Simple 
Sequence Repeats. Trends in Plant Science, 1, 215-222.

[32] Thomas, M.R. and Scott, N.S. (1993) Microsatellite Repeats in Grapevine Reveal DNA Polymorphisms When Analysed as Sequence-Tagged Sites (STSs). Theoretical and Applied Genetics, 86, 985-990. https://doi.org/10.1007/BF00211051

[33] Bowers, J.E., Dangl, G.S., Vignani, R. and Meredith, C.P. (1996) Isolation and Characterization of New Polymorphic Simple Sequence Repeat Loci in Grape (Vitis vinifera L.). Genome, 39, 628-633. https://doi.org/10.1139/g96-080

[34] Scott, K.D., Eggler, P., Seaton, G., Rossetto, M., Ablett, E.M., Lee, L.S. and Henry, R.J. (2000) Analysis of SSRs Derived from Grape ESTs. Theoretical and Applied Genetics, 100, 723-726. https://doi.org/10.1007/s001220051344

[35] Mahalakshmi, V., Aparna, P., Ramadevi, S. and Ortiz, R. (2002) Genomic Sequence Derived Simple Sequence Repeats Markers A Case Study with Medicago spp. Electronic Journal of Biotechnology, 5, 13-14. https://doi.org/10.2225/vol5-issue3-fulltext-2

[36] Becker, J. and Heun, M. (1995) Barley Microsatellites: Allele Variation and Mapping. Plant Molecular Biology, 27, 835-845. https://doi.org/10.1007/BF00020238

[37] Temnykh, S., Park, W.D., Ayres, N., Cartinhour, S., Hauck, N., Lipovich, L., Cho, Y.G., Ishii, T. and McCouch, S.R. (2000) Mapping and Genome Organization of Microsatellite Sequences in Rice (Oryza sativa L.). Theoretical and Applied Genetics, 100, 697-712. https://doi.org/10.1007/s001220051342

[38] Senior, M.L. and Heun, M. (1993) Mapping Maize Microsatellites and Polymerase Chain Reaction Confirmation of the Targeted Repeats Using a CT Primer. Genome, 36, 884-889. https://doi.org/10.1139/g93-116

[39] Weber, J.L. (1990) Informativeness of Human $(d C-d A)_{n} \cdot(d G-d T)_{n}$ Polymorphisms. Genomics, 7, 524-530. https://doi.org/10.1016/0888-7543(90)90195-Z

[40] Panaud, O., Chen, X. and McCouch, S.R. (1995) Frequency of Microsatellite Sequences in Rice (Oryza sativa L.). Genome, 38, 1170-1176. https://doi.org/10.1139/g95-155

[41] Morgante, M., Hanafey, M. and Powell, W. (2002) Microsatellites Are Preferentially Associated with Nonrepetitive DNA in Plant Genomes. Nature Genetics, 30, 194-200. https://doi.org/10.1038/ng822

[42] Nadeem, M.A., Nawaz, M.A., Shahid, M.Q., Doğan, Y., Comertpay, G., Yıldız, M., Hatipoğlu, R., Ahmad, F., Alsaleh, A., Labhane, N. and Özkan, H. (2018) DNA Molecular Markers in Plant Breeding: Current Status and Recent Advancements in Genomic Selection and Genome Editing. Biotechnology \& Biotechnological Equipment, 32, 261-285. https://doi.org/10.1080/13102818.2017.1400401

[43] Kalia, R.K., Rai, M.K., Kalia, S., Singh, R. and Dhawan, A.K. (2011) Microsatellite Markers: An Overview of the Recent Progress in Plants. Euphytica, 177, 309-334. https://doi.org/10.1007/s10681-010-0286-9

[44] Weber, J.L. and May, P.E. (1989) Abundant Class of Human DNA Polymorphisms Which Can Be Typed Using the Polymerase Chain Reaction. American Journal of Human Genetics, 44, 388-396.

[45] Yu, Y., Zhang, Y., Yin, L. and Lu, J. (2012) The Mode of Host Resistance to Plasmopara viticola Infection of Grapevines. Phytopathology, 102, 1094-1101.

https://doi.org/10.1094/PHYTO-02-12-0028-R 


\section{Supplementary Files}

Table S1. List of various grape accessions used in the present study.

\begin{tabular}{|c|c|c|c|}
\hline S. No. & Variety & S. No. & Variety \\
\hline 1 & Kattakurghan & 29 & Concord \\
\hline 2 & Black Monukka & 30 & Kishmish Rozavis \\
\hline 3 & Palomino & 31 & Diamond Jubilee \\
\hline 4 & Italian Eliquena & 32 & Chasselas Blanc \\
\hline 5 & Red Globe & 33 & Fantasy Seedless \\
\hline 6 & Chardonnay & 34 & Cheema Sahebi \\
\hline 7 & Red Muscat & 35 & Crimson seedless \\
\hline 8 & Madhu Angoor & 36 & Sirius \\
\hline 9 & Viognier & 37 & Trebbiano \\
\hline 10 & Vitis Labrusca & 38 & Garganega \\
\hline 11 & Kishmish Belyi & 39 & Tsimlyanski Chernyi \\
\hline 12 & Pandhari Sahebi & 40 & Athens \\
\hline 13 & Anab-e-Shahi & 41 & Sahebi Ali \\
\hline 14 & Country Banglore & 42 & Peru white \\
\hline 15 & Black Damas Rose & 43 & Champanel \\
\hline 16 & Hussain Kadu & 44 & Grenache \\
\hline 17 & Golden Queen & 45 & Red Prince \\
\hline 18 & Black Champa & 46 & Banglore Blue \\
\hline 19 & Doradillo & 47 & Pearl of casaba \\
\hline 20 & Alden & 48 & Tempranillo \\
\hline 21 & Bianca & 49 & Cinsault \\
\hline 22 & Castiza & 50 & Maroo Seedless \\
\hline 23 & Black Hamburg & 51 & Reisling \\
\hline 24 & Charas & 52 & Cabernet Sauvignan \\
\hline 25 & Champion & 53 & CBR \\
\hline 26 & Convent large Black & 54 & Muscandinia Rotundifolia \\
\hline 27 & Barbarossa & 55 & SV 12309 \\
\hline 28 & Black Round & 56 & SV 123640 \\
\hline
\end{tabular}

Table S2. The list of primer sets for the identified markers of $R P V 1$ locus associated with DM resistance.

\begin{tabular}{cc}
\hline Marker & \multicolumn{1}{c}{ Sequence } \\
\hline \multirow{2}{*}{ TCT } & 5' GTTAGGGTTGCACAATCTCCTC 3' \\
& 5' GAAATTATAGCGGGTGTCTTCG 3' \\
\hline
\end{tabular}




\begin{tabular}{|c|c|}
\hline Continued & \\
\hline TAAAAA & $\begin{array}{l}\text { 5' CTGGTGTGACTGCCATGTTAAT 3' } \\
\text { 5' ACGTCTTCTCTTACGGTTTCCA 3' }\end{array}$ \\
\hline ATT & $\begin{array}{l}\text { 5' ATTTTCTGTTTCCCTTGATCCC 3' } \\
\text { 5' CCACACTTCTCAATGTTCGCTA 3' }\end{array}$ \\
\hline AGGAG & $\begin{array}{l}\text { 5' CTTCCATCCCTCGAACAACTAC 3' } \\
\text { 5' GTTTTCTTCATAACCGGCAAAG 3' }\end{array}$ \\
\hline AGAGGG & $\begin{array}{l}\text { 5' TGATGTTCGTATGGTTGGGATA 3' } \\
\text { 5' CCATTCACGATGTCCAAGTAAA 3' }\end{array}$ \\
\hline GTAAT & $\begin{array}{l}\text { 5' TGCTTTCTCTCTCTAATTGCCC 3' } \\
\text { 5' CACCTATCAAACTCCTGCACAA 3' }\end{array}$ \\
\hline GAAGT & $\begin{array}{l}\text { 5' TTGTGCAGGAGTTTGATAGGTG 3' } \\
\text { 5' ATTAACATGGCAGTCACACCAG 3' }\end{array}$ \\
\hline TGAAT & $\begin{array}{l}\text { 5' TTGTGCAGGAGTTTGATAGGTG 3' } \\
\text { 5' ATTAACATGGCAGTCACACCAG 3' }\end{array}$ \\
\hline TATCTC & $\begin{array}{l}\text { 5' CTGATAGCATTGGAGACTTGGA 3' } \\
\text { 5' AACTTTTCATGTTCCСТCCСTT 3' }\end{array}$ \\
\hline TTCTTT & $\begin{array}{l}\text { 5' GGTATCTTCGTTGGGATGGATA 3' } \\
\text { 5' TCTGACATTTGACTGAGCTTCC 3' }\end{array}$ \\
\hline AAT & $\begin{array}{l}\text { 5' GAAGCCTCAAGCCCACTAACTA 3' } \\
\text { 5' AGGGGCAACTCTCTGTCTCTATT 3' }\end{array}$ \\
\hline ATAAA & $\begin{array}{l}\text { 5' GAAGCCTCAAGCCCACTAACTA 3' } \\
\text { 5' AGGGGCAACTCTCTGTCTCTATT 3' }\end{array}$ \\
\hline
\end{tabular}

